\title{
An eye on the future
}

\author{
The next president of Germany's Max Planck Society is putting \\ aside a glittering research career in developmental biology to wrestle \\ with politics, ethics and budgets, says Alison Abbott.
}

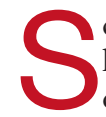
cientifically, Peter Gruss seems to have it all. He is the most highly cited developmental biologist in Germany, and just two years ago he launched a groundbreaking project to open up the black box of brain development.

So when he was approached by the committee looking for a successor to Max Planck Society (MPS) president Hubert Markl, it must have been tempting to politely decline. The political climate for research in Germany is stormy - the issue of human embryonic stem (ES) cells is the focus of widespread public hostility — and the current economic downturn means that budgetary expansion is out of the question.

Gruss admits he was torn: "I was surprised when I was approached, and it took me at least a week to consider the position, since I am at such a critical point in my research." But accept he did, and last week his nomination to take over from Markl as head of Germany's premier research organization was confirmed by the MPS's governing senate.

Gruss, who runs a 30-strong lab at the Max Planck Institute for Biophysical Chemistry in Göttingen, is best known for his work on the Pax genes in mice. His group, for example, identified the central role of a gene called Pax6 in the development of the eyes and forebrain. Two years ago, having just turned 50, he launched a major project to systematically determine the genetic basis of the development of the cerebral cortex, about which little is known. Nearly half of the researchers in his lab are now busy developing the wide range of functional genomic techniques that will be run in parallel to crack the problem.

$\mathrm{He}$ is certainly not the archetypal MPS president. Markl had already served as head of the DFG, Germany's main agency for research grants, before taking over as the society's president in 1996, and was well known as a political animal. Gruss, by contrast, is the scientist's scientist — informal, approachable

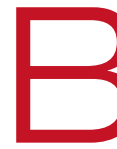

asic research establishes the basis for the future. We don't just do it for fun.

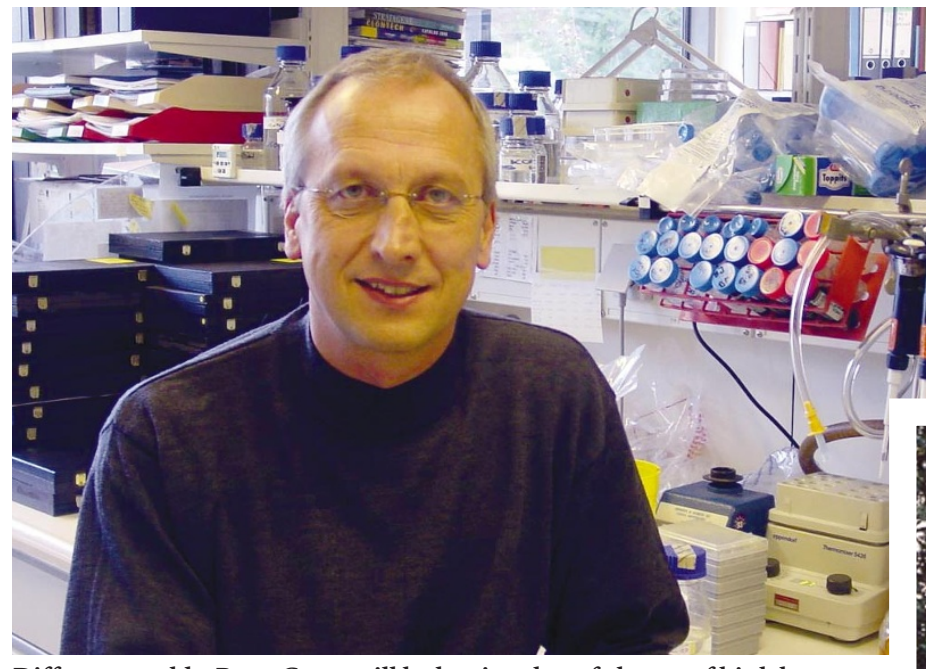

Different worlds: Peter Gruss will be leaving the safe haven of his laboratory for the politics of the Max Planck Society headquarters in Munich (right).

and happiest shooting the breeze with his fellow researchers.

So does Gruss have the political skills to succeed in one of the most important and high-profile jobs in German science? One positive sign is his engagement in recent months in Germany's contentious debate over human ES-cell research. Gruss has repeatedly spoken out on the importance of this work, without which it may not be possible to develop therapies based on adult stem cells — touted by opponents of ES-cell research as a viable alternative.

This message still needs reinforcing, says Gruss. "Many people believe that scientists will demand a continuous supply of surplus embryos, whereas what we really want are a few good cell lines to help us learn how they differentiate and therefore how to reverse differentiation - that is, how to reprogramme adult stem cells."

Gruss admits to a personal interest in the debate. Two years ago he founded the company DeveloGen to exploit his group's discovery that one of the mouse Pax genes causes adult pancreatic stem cells to differentiate into insulin-producing cells. $\mathrm{He}$ is excited about the therapeutic potential in diabetes, and is concerned that restrictions on ES-cell research will hold back the entire field. "I am defending my research area," he says.

But he accepts that it may not be easy to be so outspoken as MPS president. "I will have to consider the views of other members of the MPS when I am speaking on behalf of the whole society."

Gruss will take over the reins from Markl in June, and acknowledges that he has a tough act to follow. Markl has made significant headway in tackling long-standing problems such as a lack of flexibility in adopting new areas of research and an absence of women in top positions. He also handled the unpleasant business of closing institutes in western Germany so that new institutes in the east could flourish.

Gruss plans to continue Markl's initiatives to make the MPS more dynamic. He will also face the challenge of replacing nearly a third of the MPS's 260 research directors during his six-year tenure, as the generation of baby-boomers comes to retirement.

What Gruss would really love to achieve is a major increase in funding for the MPS. "We need to make it clear to the public that basic research establishes the basis for the future of society, and we don't just do it for fun," he says. "We need to be internationally competitive. We must think in terms of budget increases much higher than in the past."

Then, checking an enthusiasm that might be interpreted as naivety, he adds: "But I am very pragmatic and fully aware that it has to be seen in the context of general economic growth - one cannot demand the impossible." It seems that Gruss is already adapting to the political realities of his new role.

Alison Abbott is Nature's senior European correspondent. 